\title{
Research of the Corporate Performance Evaluation Indicators Based on the Stakeholder Theory
}

\author{
Qi Zhang \\ Economics School, Beijing Wuzi University, Beijing, China \\ Email:
}

Received 15 May 2015; accepted 11 July 2015; published 14 July 2015

\begin{abstract}
The traditional evaluation system of corporate performance by maximizing stakeholders' value has increasingly shown its limitations, and the establishment of performance evaluation system based on stakeholder theory is particularly important. This paper describes stakeholders' focuses on corporate performance evaluation and analyzes the importance of each of these concerns. Finally, based on the summary of the preceding analysis, this paper analyses the performance evaluation system based on the stakeholder theory, which is oriented by the maximization of corporate value, and proposes different focuses of the corporation according to different sectors and different circumstances.
\end{abstract}

\section{Keywords}

Stakeholder Theory, Maximization of Corporate Value, Performance Evaluation Indicator System

\section{Introduction}

The purpose of a corporation is to create corporate value, which determines that the corporate financial management must serve to increase the corporate value and maximize the corporate value. Traditionally, the evaluation of the maximization of the corporate value is mainly measured by the maximization of stakeholder wealth. Companies need stakeholders' funds to set up. The traditional theory, which takes the maximization of stakeholder wealth as the evaluation criteria of the maximization of corporate value, takes into account the operating performance of corporate, investors' wealth, corporate finance, and many other factors, and then it seems to be very reasonable. However, with the development of modern management theory, the financial management that just considers the stakeholder wealth is increasingly showing its potential shortcomings [1]. Therefore, the theory that just takes the stakeholder wealth as the evaluation criterion of the corporate performance is unable to adapt to the changes and demands of the contemporary socio-economic situation. When measuring the maximization of corporate value, we must fully consider the interest needs of corporate stakeholders and find the equilibrium point of the needs of various stakeholders, and finally summarize the performance evaluation system in line with the requirements of each stakeholder. 


\section{The Limitations of the Traditional Evaluation Method}

Corporate performance evaluation system is an important criterion for measuring business results. It is an organic whole made up of a series of evaluation systems, evaluation indicators and evaluation methods related to the performance evaluation. Scientific and rational corporate performance evaluation system is a prerequisite for objective and impartial evaluation of corporate performance. Only by establishing a proper performance evaluation system, can the corporate timely find existing problems and deficiencies in their operations, so as to ensure the steady development of corporate in the exploration, and continue to be successful.

Traditionally, the corporate performance evaluation is primarily assessed through stakeholder wealth; the maximization of the corporate value is also measured based on the maximization of stakeholder wealth. Stakeholders as the company's most important partners, play a vital role in the decision-making of the capital and operation of the corporate. Therefore, taking the stakeholder wealth as a measure of the corporate value seems understandable. However, with the development of modern management theory, simply considering the stakeholder wealth to measure the corporate value starts to show some flaws. First of all, the maximization of stakeholder wealth is mainly oriented by the maximization of stock price. However, on a worldwide scale, the listed companies, after all, account for only a small part of all corporate, and most of the non-listed companies' stakeholder wealth cannot be measured through the public-listed stocks. Even if it is a listed company, its stock price will be under the influence of various factors, and its response to stakeholder wealth also may be distorted. Competition in the market, market expectations, and non-economic factors such as government policy changes will also affect stock prices, and the stock prices influenced by these factors can't objectively and accurately reflect the stakeholder value. In addition, the maximization of stakeholder wealth only takes into account the interests of the stakeholders, and stakeholders are often willing to harm the interests of other stakeholders in order to realize their benefits. The existence of corporate is not just the results of operation of a single capital chain. If corporate simply pursue the maximization of stakeholder wealth, while ignores the interests of its creditors, suppliers, customers, employees, managers, government and even the society as a whole, it is extremely unfavorable to the long-term development of corporate [2].

Previous studies have demonstrated that tradable stock stakeholders ' equity has positive impact on corporate performance, while the controlling stakeholders' equity has a negative effect on corporate performance. Controlling stakeholder's equity is relatively closed, and when making decisions the controlling stakeholders often only consider their own interests rather than taking into account the overall interests. Therefore, the evaluation of corporate performance mainly measured by the maximization of stakeholder wealth has big deficiencies, and this assessment method cannot measure the corporate performance completely and objectively.

Companies can't independently achieve profitability only rely on their own. No matter producing goods or providing services, corporate always need to have a basic raw material suppliers and consumers of the end product, which decides that the overall operation of the corporate is inseparable from contact with suppliers and customers. Only when the corporate has a good reputation in the suppliers and customers can it achieve the continuity of the forward and backward of their products and services, so as to truly realize its value in the market.

Corporate could not operate automatically. The operation of the corporate requires the involvement and coordination of the staff. If the corporate ignores the interests of the employees and their managers in the process of corporate management, it will inevitably lead to moral hazard and adverse selection problems. Therefore, only by guaranteeing the interests of employees and managers can the corporate achieve the unification of personal goals and business objectives, so as to truly improve corporate value.

The most basic premise of the existence of the corporate is to comply with government laws and regulations. Following the government's call and arrangement is a prerequisite for the corporate to exist and develop [3]. And in the daily business activities, the corporate is likely to damage the collective interests of the public in the pursuit of the interests of small groups, which requires the government to carry out necessary intervention and regulation. Only when the business interests integrate with the society interests can the corporate truly have a sustained and healthy development. It is also the decisive condition for the corporate to continuously accumulate wealth and achieve the corporate value.

Businesses do not exist in an independent individual; their survival and development must rely on a complete harmony of the interests' chain. In the process of measuring the business value, we cannot only consider the realization of stakeholder value as a sign of its overall development, but also take into account the impact on other stakeholders, which also makes the corporate performance evaluation based on the stakeholder theory objectively necessary. 


\section{Expectations and Requirements on Corporate Performance Evaluation System to Maximize the Corporate Value from Stakeholders}

\subsection{Stakeholders from Capital Markets}

1) Stockholders' value growth is core to corporate performance.

Companies exist to provide profit with stakeholders, as owners of companies, who pursue value growth through corporate operations and businesses [4]. For a few decades, the core objective of modern investments is the maximization of the stakeholders' value. Until stakeholders' value accumulated, owners will have passion and confidence in corporate future operation and development, and further to take interventions on companies.

For corporate performance, stakeholders mainly focus on return on capital invested and corporate comprehensive risk; return on total assets, rate of return on common stockholders' equity, profit margin, turnover of total assets and equity multiplier are the main focused indicator. When the five indicators meet the expectation of stakeholders, the stakeholders' value can be achieved.

2) Protection of creditors' interests is the key to corporate performance.

The realization of corporate profit is established on cost operations. Usually, capital for the expansion of corporate reproduction cannot be realized by corporate accumulation; therefore, external financing becomes a must for corporate development and stakeholders are fundamentally critical to the realization of corporate value. Creditors and stakeholders both act as investors of companies; however, their roles and rights are definitely different. Stakeholders influence corporate operations through strategic management, whose liability is limited amount of contribution to the company; otherwise, creditors bearing more risks are not involved in corporate management but rewarded with low fixed interests. The sound stability of the credit relationship makes companies to raise funds in a timely manner possible [5]. The creditors' value must be taken into account in the process of maximization of corporate value. Creditors focus companies mainly on return on capital invested and corporate solvency. Time interest earned ratio, profit margin, current ratio, turnover of total assets and asset-liability ratio are mainly-concerned indicators.

\subsection{Stakeholders from Product Markets}

1) Connecting interests of suppliers is the promoting factor of corporate performance.

Suppliers act as the upstream part of corporate production, whose quality of supplies, time, quantity etc. are all critical to corporate production. If companies blindly pursue self-interests but harm the interests of suppliers, like not paying on time, not delivery on time, those behaviors will lead to estrangement between companies and suppliers, even influence corporate production efficiency. Raw materials and production operations can run sustainably and lay foundations for maximization of corporate value when strategic partnership is established between companies and suppliers [6].

Suppliers often focus on ability to pay, purchasing quantity and performance. The main indicators are cash ration, inventory turnover and overdue payment times. When the fundamental interests of suppliers are achieved, they are likely to improve quality of raw materials and supply timeliness, which makes disputes during supplying process more easily settled and continuity of corporate value creation realized.

2) Maintaining interests of customers guarantees corporate performance.

Whether the interests of customers, who act as direct sufferers of corporate products and services, are maintained is critical to corporate sustainability. Most of goods and services in the market have a large number of competitors and substitutes. Companies need to establish sound relationship with customers to take advantage over so many identical goods and services so as to win trust of customers. When customers realized the maximization of their interests, they are more likely to tend to recommend corporate brand to other more customers; then to expand channels of goods and services and to achieve more value [7]. Customers usually focus on quality of goods and services, inventory turnover and after-sale service. Only when they meet the demands for goods and services from customers and take the interests of customers as a starting point can companies obtain confidence and loyalty from customers to realize sustainable corporate value.

\subsection{Stakeholders from Companies}

1) Guaranteeing benefits of employees is fundamental to corporate performance.

Employees, direct creator of corporate value, play a significant role in companies. However effective the in- 
stitution managers make, the key is whether employees can obey and take it into practice. If employees can obtain the outcomes matching their inputs, they will lose enthusiasm for work, further to do harm impact on improvement on corporate performance. Thus, companies need to adhere to the idea of people oriented to make employees warm and willing to be involved in the corporate family and to make unremitting contributions to corporate value creation. Employees focus on return on work, performance confirmation, skill cultivation and comfort working environment. When they meet the needs of employees for both material and spirit level, companies can run their businesses and operations normally and realize more value [8].

2) Interests of managers are direct guarantee to corporate performance.

Corporate managers are usually outsider. Because they do not possess corporate ownership and control, corporate managers are likely to pursue self-interests by adverse selection or hazard risk. Therefore, protecting managers' interests becomes inevitable for corporate governance. Only when their reasoning interests are achieved will they have stronger passion to further corporate development and create more value. Focus of managers is mainly on corporate performance, salaries and appreciation from companies, and support. The measurements are profit margin, sustainable growth rate, salary and reward, trust and support from companies.

\subsection{Government and Social Responsibility}

1) Accordance with government regulations and regulatory tax is the premise to corporate performance.

Government plays a guiding and monitoring role in corporate performance. As for government, the measurement to corporate performance is that corporate institution is in accordance with government regulations and regulatory tax. Government focuses corporate performance on net margin. Only when they obtain expected margin can companies guarantee regulatory tax. Thus, companies need to announce related information correctly in time to make government meet demands for interests; and further to gain support of future development from government. As survey showed us, listed companies announce more information and indications than non-listed ones and large companies announce more than medium and small companies from the perspective indications of corporate capability, efficiency, level, competency, management, strategy, top-managers, managers and quality of employees. Therefore, companies can pursue good performance over their rivals as long as they guarantee government's interests. Also, only in this way can companies obtain power source to future development [9].

2) Undertaking social responsibility is the potential to corporate performance.

With capital accumulated and resource integrated, global climate crisis drove the concept of corporate citizen to stage. Companies, as a part of social activities, play a significant role in the society. If companies can undertake social responsibility to take an active part into social charity, there will be more fresh power source and more social trust inputting to companies, which is favorable to companies' enhancing the public credibility, building talent highland and expanding market share. Companies should take social responsibly into performance evaluation, truly playing role of citizen and seeking more welfare for society.

\section{Performance Evaluation System for Maximization of Corporate Value Based on Stakeholder Theory}

It is obvious from focuses of different stakeholders that corporate performance evaluation for maximization of corporate value is established based on guaranteeing interests of different stakeholders. Among those focused indicators, operational performance and capital structure are common concerns but different stakeholders have different requirements for corporate performance. As graph exhibited, direct corporate stakeholders focus on corporate asset situation and operational performance; in addition, they have different evaluation standards to corporate performance according to their own needs. As for indirect corporate stakeholders, they focus on corporate level of sales. Steady level of sales can guarantee sustainable performance and further create corporate value to achieve maximization of corporate value. Companies in different industries will have different focuses on performance (Figure 1).

For manufacturing industry, which is an indirect customer-oriented industry, suppliers of raw materials and distributors of products are relatively stable. Companies need to pay high attention to direct stakeholders, especially for interests of employees. Only when interests of employees are protected fully and effectively can production run as planned and supply high quality products for different stakeholders. Since manufacturing industry may have stronger impact on environmental pollution, manufacturing companies need to take responsibility to 


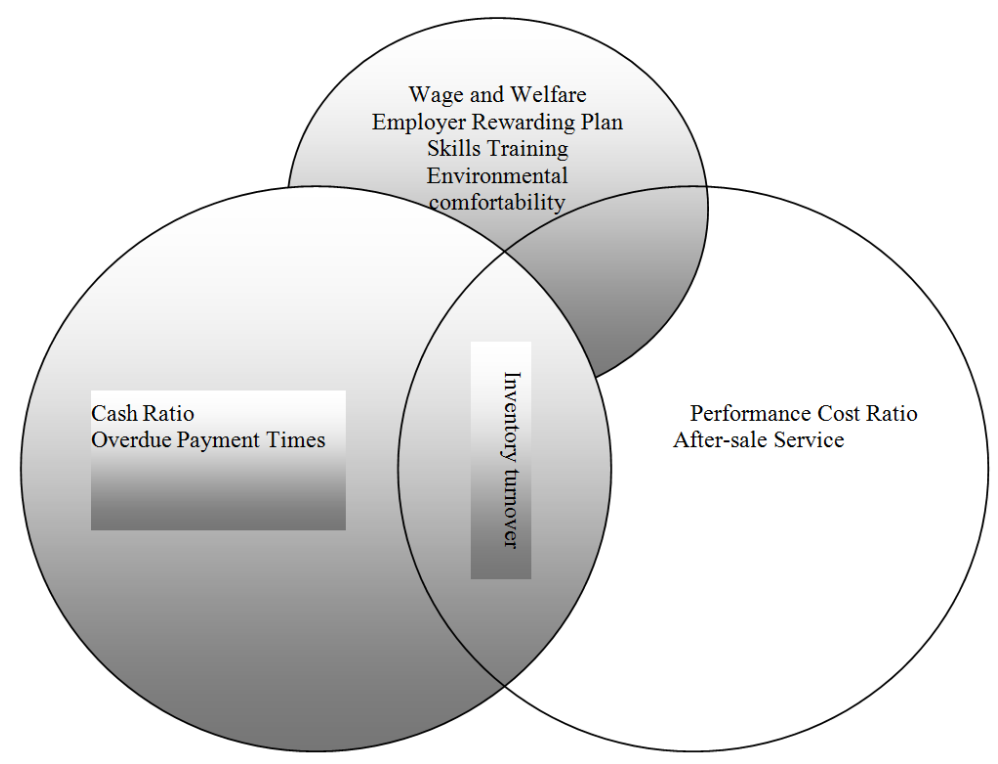

Figure 1. Performance evaluation indicators.

handle pollution to maintain corporate image and achieve sustainable development. In terms of retailing industry, since retailing industry mainly faces suppliers and customers who consume their goods and services, the relationship with them can affect corporate resources and future development directly. Therefore, retailing companies must lay strong stress on interests of suppliers and customers and further to realize interests of direct stakeholders. Only in this way can companies play the role of bridge to maintain good relationship with suppliers and customers to achieve corporate value.

The corporate performance evaluation should be emphasized on different directions according to different situations. In perfect competitive industry, the corporate public image and service quality are relatively emphasized by consumers, because there are verified suppliers of same goods and services. As a result, the corporate performance evaluation should be emphasized on clients and social responsibility. Only with premium services for clients and high social responsibility, can the corporate build a positive image in public and gain high social popularity so as to win more trust and support in intense competition. When the whole industry turns down, the corporate performance evaluation should also be adjusted. Because of the uncertainty of the industry's prospect, debtors probably cancel the investment because they are unwilling to bear too many risks. As a result, debtors' interests should be the first aspect to be emphasized when the corporate performance is evaluated. Only when debtors' interests are satisfied, can the corporate gain enough funds to maintain management and go through difficulties while the industry is going down. Correct decision-making by the managers is crucial to build debtors' trust. Managers should summarize the advantages of the corporation through industrial analysis and make appropriate strategic plans, so that the corporation can keep relatively leading competitiveness in the market when the external environment is going down, and debtors can have positive attitudes about the future development of the corporation. All in all, debtors' interests and managers' demands can be simultaneously satisfied, and then the corporation can truly have healthy and stable development.

Above all, when the corporation evaluates the performance, the most important focus should be found out, according to the corporation's own characteristics, industrial characteristics, external environment and different interests of different parties related. Starting from the focus and integrating the key interests of different parties, the corporation should continuously satisfy the demand of different interest parties so as to maximize the corporation's value.

\section{Acknowledgements}

This thesis is supported by the 2013 Beijing Municipal Education Commission's specific funding program: Research on Public Service Incubator of Small Enterprises of Creative Industries in Beijing, and 2011 Beijing Language and Culture University's social-science project: Research on Internalization of RMB (Project No. 
11GH05).

\section{References}

[1] Hou, W. (2009) Financial Indicators in Evaluating Performance in the Corporation. Business Economy, 24.

[2] Zhang, Z.G., Liang, Z.G. and Yin, K.G. (2012) Research on Corporates' Social Responsibilities from the Prospective of Stakeholders. China Soft Science, 2.

[3] Wang, X.W. and Chen, H. (2011) Research on the Relationship between Corporate Social Responsibility and Corporate Value. Management Science, $\mathbf{6}$.

[4] Liu, X.M. (2012) Alliance Combination: Value Creation and Administration Mechanism. China Industrial Economics, 6.

[5] Liu, G. (2012) Stakeholders' Value Condition, Cooperative Relationship and Network Performance. Journal of Systems Engineering, 6.

[6] Paulin, M., Ferguson, R.J. and Bergeron, J. (2006) Service Climate and Organizational Commitment: The Importance of Customer Linkages. Journal of Business Research, 59, 906-915. http://dx.doi.org/10.1016/j.jbusres.2006.03.004

[7] Ulaga, W. and Eggert, A. (2006) Relationship Value and Relationship Quality: Broadening the Nomological Network of Business-to-Business Relationships. European Journal of Marketing, 40, 311-327.

[8] Laplume, A.O., Sonpar, K. and Litz, R.A. (2008) Stakeholder Theory: Reviewing A Theory That Moves Us. Journal of Management, 34. http://dx.doi.org/10.1177/0149206308324322

[9] Sahadev, S. (2008) Economic Satisfaction and Relationship Commitment in Channels: The Moderating Role of Environmental Uncertainty, Collaborative Communication and Coordination Strategy. European Journal of Marketing, 42, 178-195. http://dx.doi.org/10.1108/03090560810840961 